Le Lait (1985), 65 (649-650), 103-121

\title{
Characterization of an L-serine dehydratase activity in permeabilized cells of Brevibacterium linens ATCC 9175
}

\author{
Dominique HAMOUY and M. J. DESMAZEAUD*
}

\begin{abstract}
SUMMARY
Brevibacterium linens ATCC 9175 produces large quantities of, ammonia and pyruvate from $L$-serine. This reaction occurs via an L-serine dehydratase (EC.4.2.1.13), whose activity is maximal at the end of exponential growth on rich medium and which abruptly decreases at the beginning of the stationary phase. It is not possible to extract the soluble form of the enzyme without a total loss of activity. Subcellular localization studies after creating stable protoplasts with lysozyme have shown that a part of the activity is bound to cell membranes. A stable form of activity has been obtained by treating the cells with Triton $X-100$ and the main properties of the enzyme have been studied with this insoluble form. The apparent Michaelis constant is $50 \mathrm{mM}$ and the Vmax is 200 nmol of pyruvate formed per minute and per $m g$ of dry extract. The optimum $p H$ is included between 8.5 and 9.4 and activity is very stable between 8.0 and 9.4. The enzyme is slightly thermostable. The exclusive substrate is $L$-serine. D-serine and 2-aminoethanol are competitive inhibitors. L-serine dehydratase activity is strongly inhibited by o-phenanthroline. Pyridoxal phosphate is required for maximum activity.
\end{abstract}

Key words : Brevibacterium linens - L-serine dehydratase - Serine catabolism.

I.N.R.A., Laboratoire de microbiologie laitière, Centre de recherches zootechniques - 78350 Jouy-en-Josas (France).

* To whom reprint requests should be sent. 


\section{RESUME}

\section{CARACTERISATION D'UNE ACTIVITE L-SERINE DESHYDRATASE DANS DES CELLULES PERMEABILISEES DE BREVIBACTERIUM LINENS ATCC 9175}

Brevibacterium linens ATCC 9175 produit de grandes quantités d'ammoniac et de pyruvate à partir de la L- sérine. Cette réaction est due à une enzyme de type L- sérine déshydratase (E.C. 4.2.1.13) dont l'activité est maximum en fin de croissance exponentielle dans un milieu complexe. Elle décroît ensuite rapidement dès le début de la phase stationnaire de croissance. Il n'a pas été possible d'extraire l'enzyme sous une forme soluble sans avoir une perte totale de son activité. Des essais de localisation cellulaire de l'activité ont été tentés après obtention par action du lysozyme de protoplastes stables. Il est montré qu'une partie de l'activité est liée à la fraction membranaire de la cellule. Par contre, une forme stable de l'activité enzymatique était obtenue par traitement des cellules au Triton X 100. Les principales propriétés de cette enzyme ont donc pu être étudiées sous cette forme insoluble.

La constante apparente de Michaelis est de $50 \mathrm{mM}$ et la vitesse maximum apparente de 200 nmoles de pyruvate formé par minute et par mg d'extrait sec cellulaire. Le $\mathrm{pH}$ optimum est compris entre 8,5 et 9,4. L'activité est très stable entre 8,0 et 9,4. La température optimale d'action est comprise entre 26 et $35^{\circ} \mathrm{C}$. Les cinétiques d'inactivation thermique montrent que l'enzyme est stable jusqu'à $30^{\circ} \mathrm{C}$ mais qu'elle s'inactive rapidement à $40^{\circ} \mathrm{C}$. L'enzyme est très spécifique puisque seule la L- sérine est substrat. La D- sérine et le 2- aminoéthanol sont des inhibiteurs compétitifs. D'autre part, cette activité L- sérine déshydratase est fortement inhibée par l'ortho- phénanthroline. L'E.D.T.A. entraîne au contraire un effet stimulant de l'activité aux concentrations inférieures à $10^{-3} \mathrm{M}$, puis devient inhibiteur aux concentrations supérieures. Le pyridoxal phosphate est exigé pour obtenir une activité maximum.

Mots clés : Brevibacterium linens - L-sérine déshydratase - Catabolisme de la sérine.

\section{INTRODUCTION}

Among the microorganisms which play a role in cheese ripening, the coryneform bacteria and especially Brevibacterium linens are involved (Boyaval and Desmazeaud, 1983). Their quantitative importance has in fact been shown on the surface of a large number of cheeses including Camembert (Richard and Zadi, 1983), Livarot, Munster, Maroilles, Gruyere, Trappist, etc. (Ades and Cone, 1969; El Erian, 1972; Veisseyre, 1975; Accolas et al., 1978; Brandl, 1978). The 
general metabolism of $B$. linens, however, remains poorly understood. Although these proteolytic and lipolytic activities have been studied in the past (Thomasow, 1950; Friedman et al., 1953; Hosono, 1968; Sorhaug and Ordal, 1974; Foissy, 1978 a, b, c), the catabolism of amino acids in this species and its effect on the appearance of flavor constituents is only beginning to be understood. It has been shown that serine is deaminated to a considerable extent by different strains of $B$. linens (Hemme et al., 1982). Ammonia, which is present in all ripened rinds but at varying concentrations is, according to Dumont and Adda (1978) the only volatile amine to play a genuine role in cheese flavoring.

Prior work (Hamouy, 1983) has shown that L-serine is catabolized by $B$. linens ATCC 9175 by an L-serine dehydratase (EC.4.2.1.13). This enzyme degrades L-serine to ammonia and pyruvate and thus plays a key role in serine and glycine metabolism (Morris, 1963). L-serine dehydratase and L-threonine dehydratase had long been considered to be the same enzyme. However, since the work of Benziman et al. (1960) and Carter and Sagers (1972), who proved the existence of an L-serine dehydratase specific for L-serine in Clostridium acidiurici, similar activities have been reported in extracts of other microorganisms, such as Arthrobacter globiformis (Bridgeland and Jones, 1965; Gannon et al., 1977), Escherichia coli (Alföldi et al., 1968), E. coli K12 (Isenberg and Newman, 1974), Bacillus cereus, Salmonella typhimurium (Rasko et al., 1969), Pseudomonas cepacia (Wong and Lessie, 1979), Bacillus alvei (Griffiths and De Moss, 1970), and Corynebacterium spp. (Morikawa et al., 1974). In Brevibacterium linens, on the other hand, the existence of this enzyme has not yet been demonstrated. The present report described the general properties of the L-serine dehydratase extracted from B. linens ATCC 9175.

\section{MATERIALS AND METHODS}

\section{A. Organism}

The strain utilized was Brevibacterium linens ATCC 9175.

\section{B. Cell growth and harvest}

The following culture medium was used: $3 \mathrm{~g}$ soy peptone (Difco), $7 \mathrm{~g}$ bactotryptone (Difco), $5 \mathrm{~g}$ yeast extract (Difco), $5 \mathrm{~g}$ of $60 \%$ sodium DL-lactate (Sigma, grade IV), $5 \mathrm{~g} \mathrm{NaCl}$ (Prolabo), $2.5 \mathrm{~g} \mathrm{~K}_{2} \mathrm{HPO}_{4}$ (Prolabo), distilled water q.s. $1000 \mathrm{ml}$. The $\mathrm{pH}$ was adjusted to 7.0 before autoclaving. The medium was inoculated at $3 \%(\mathrm{v} / \mathrm{v})$ with a preculture containing $10^{9}$ cells $/ \mathrm{ml}$. Cells were grown at $26^{\circ} \mathrm{C}$ with agitation $(120 \mathrm{rpm})$ and were harvested by centrifuging at $5000 \mathrm{~g}$ at $4^{\circ} \mathrm{C}$ for 10 minutes. The pellet was washed with a saline solution containing $0,25 \% \mathrm{~K}_{2} \mathrm{HPO}_{4}$ and $0.5 \% \mathrm{NaCl}$, pH 7.0. 


\section{Enzyme extraction}

\section{Permeabilization with Triton $X-100$}

The technique of Miozzari et al. (1978) was used. Cells were harvested, washed and then resuspended in $50 \mathrm{mM}$ TRIS- $\mathrm{HCl}, \mathrm{pH}$ 9, containing $0.05 \%(\mathrm{v} / \mathrm{v})$ Triton X-100. The treated suspension contained $13 \mathrm{mg}$ dry extract $/ \mathrm{ml}$. After freezing at $-20^{\circ} \mathrm{C}$ for at least $15 \mathrm{~h}$, the cells were thawed at $26^{\circ} \mathrm{C}$. The resulting cell suspension was used directly as the enzyme extract.

\section{Permeabilization with toluene}

The techniques used have been described by Gannon et al. (1977) and Serrano et al. (1973).

Solubilization with sodium deoxycholate (DOC)

The technique used has been described by Regnier and Thang (1979).

\section{Sodium dodecyl sulfate (SDS) solution}

Cell extracts were solubilized with SDS at a final concentration of $0.2 \%(\mathrm{w} / \mathrm{v})$ for $10 \mathrm{~min}$ at $26^{\circ} \mathrm{C}$.

\section{Lysis with egg white lysozyme}

A suspension at $2.6 \times 10^{12}$ cells $/ \mathrm{ml}$ was treated with $40,000 \mathrm{U}$ of lysozyme $/ \mathrm{ml}$ (Sigma) at a final concentration of $40 \mu \mathrm{g} / \mathrm{ml}$. Lysis was carried out at $26^{\circ} \mathrm{C}$, either in $50 \mathrm{mM}$ TRIS- $\mathrm{HCl}, \mathrm{pH} 9$, or in the same buffer containing $2 \mathrm{M}$ (final) sucrose. Protoplasts were recovered from hypertonic medium by centrifuging at $1000 \mathrm{~g}$ at $4^{\circ} \mathrm{C}$ for $1 \mathrm{~h}$. An aliquot was then suspended in $50 \mathrm{mM}$ TRIS- $\mathrm{HCl}, \mathrm{pH} 9$, in the presence of DNase and RNase (Sigma), each at a final concentration of $40 \mu \mathrm{g} / \mathrm{ml}$, in order to lyse the protoplasts by osmotic shock.

Lysis with glass beads

Cells were suspended in $50 \mathrm{mM}$ TRIS- $\mathrm{HCl}, \mathrm{pH} 9$, containing $5 \times 10^{-5} \mathrm{M}$ pyridoxal phosphate (PLP) at a cell concentration of $13 \mathrm{mg}$ dry extract $/ \mathrm{ml}$. They were ground at $4^{\circ} \mathrm{C}$ with a Vibrogen grinder (Edmund Buhler, Tubingen, G.F.R.).

\section{Ultrasonic lysis}

A cell suspension containing $13 \mathrm{mg}$ of dry extract/ml in $50 \mathrm{mM}$ TRIS-HCl, pH9, containing $5 \times 10^{-5} \mathrm{M}$ PLP was chilled and sonicated for a total of 2 minutes. An M.S.U. 157 Ultrasonic (Meaux, France) apparatus was used, operating at 0.7 A for $30 \mathrm{~s}$ periods, followed by a 1 min cooling. The sonication tube was immersed in crushed ice during the operation. 
Crude extracts (CE) arising from these various operations were separated into a pellet $(\mathrm{P})$ and supernatant $(\mathrm{S})$ by centrifuging at $25,000 \mathrm{~g}$ for $1 \mathrm{~h}$ at $4^{\circ} \mathrm{C}$.

\section{Enzyme assay}

L-serine dehydratase activity was determined by assaying the pyruvate produced, based on the method of Friedemann and Haugen (1943). $100 \mu \mathrm{l}$ of enzyme extract were added to the following reaction mixture $500 \mu \mathrm{l}$ of buffer, $100 \mu \mathrm{l}$ of PLP $\left(5 \times 10^{-4} \mathrm{M}\right), 100 \mu \mathrm{l}$ of L-serine, $200 \mu \mathrm{l}$ of distilled water (the nature of the buffer, its $\mathrm{pH}$ and the L-serine concentration are defined for each experiment). Incubation was generally carried out at $26^{\circ} \mathrm{C}$ and the reaction was stopped by adding $500 \mu \mathrm{l}$ of $10 \%(\mathrm{w} / \mathrm{v})$ trichloroacetic acid (TCA). The mixture was held in an ice bath for $30 \mathrm{~min}$ and was then centrifuged at $5000 \mathrm{~g}$ for $10 \mathrm{~min}$ at $4^{\circ} \mathrm{C}$. $500 \mu \mathrm{l}$ of $0.1 \%$ (w/v) 2-4-dinitrophenylhydrazine (DNPH) in $2 \mathrm{~N} \mathrm{HCl}$ were then added to $500 \mu \mathrm{l}$ of supernatant. After $2 \mathrm{~min}$ at ambient temperature, $2 \mathrm{ml}$ of $2 \mathrm{~N} \mathrm{NaOH}$ were added and the «claret» color was determined at $520 \mathrm{~nm}$.

The activity of intact resting cells was determined by using the Nessler reagent to assay the ammonium ions produced. After development of the color at alkaline $\mathrm{pH}$, absorbance changes were measured at $425 \mathrm{~nm}$. A standard range was realized with ammonium sulfate solutions.

The specific activity of L-serine dehydratase is expressed as nmoles of pyruvate formed per minute and per $\mathrm{mg}$ of dry extract or per mg of protein. The protein content was determined with the method of Herbert et al. (1971) or that of Wang and Smith (1975) (modified Lowry assay for proteins in the presence of Triton X-100). Bovine serum albumin was used as standard.

\section{RESULTS}

\section{A. Influence of physiological stage of growth}

The specific activity of L-serine dehydratase increased during exponential growth reaching a maximum at the end of this phase. It then decreased abruptly at the onset of the stationary phase (fig. 1). In order to verify that this decrease was related uniquely to the physiological state of the cells and not to a decreased permeabilization of coccoid forms by Triton (since the cell wall is different from that of the rod form), a protein assay was performed on cells at 24, 48, 72 and $96 \mathrm{~h}$ of growth, after treating the samples with Triton $\mathrm{X}-100$. Total proteins and extracted proteins were then assayed and it was found that the detergent extracted the same quantities of protein from 24 and 72 hour-old cells. The decrease of specific activity is thus 


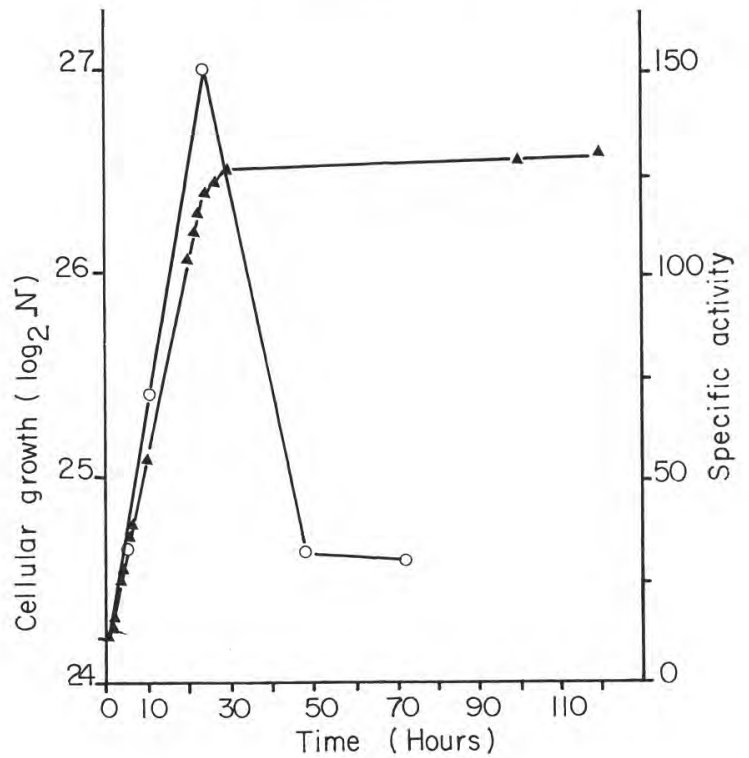

fig. 1

Influence of physiological stage on the specific activity of L-serine dehydratase

$\Delta$ - $\mathbf{A}$ : cell growth expressed as $\log _{2}$ of number of cells $/ \mathrm{mL}$.

$\mathrm{O}-\mathrm{O}$ : specific of L-serine dehydratase.

Influence de l'âge physiologique des cellules sur l'activité spécifique de la L-sérine déshydratase

$\Delta-\mathbf{\Delta}$ : croissance cellulaire exprimée en $\log _{2} d u$ nombre de cellules $/ \mathrm{mL}$. ○— $\mathrm{O}$ : activité spécifique de la L-sérine déshydratase.

not related to a decreased permeabilization by Triton X-100. The remainder of the study was carried out with cells harvested at the end of the exponential phase.

\section{B. Localization of activity}

In order to determine if the enzyme is soluble or bound to the cell envelope, assays of L-serine dehydratase activity were performed on crude extracts (CE), supernatants $(\mathrm{S})$ and pellets $(\mathrm{P})$ obtained from suspensions of cells permeabilized with Triton X-100 or with toluene. These assays were also performed with cells lysed with lysozyme, glass beads or by sonication (Table 1). The various supernatants tested were devoid of activity (Table 2) and only certain pellets, membrane fractions and protoplasts were active towards L-serine (Tables 2 and 3). Every time it was attempted to solubilize 
TABLE 1 - TABLEAU 1

Extraction yields of cell proteins with different methods of permeabilization or grinding of cells

Rendements d'extraction des protéines cellulaires par différentes méthodes de perméabilisation ou de broyage

\begin{tabular}{|c|c|c|c|c|c|c|}
\hline & $\begin{array}{l}\text { Triton } \\
\mathrm{X}-100\end{array}$ & Sonication & Toluene & $\begin{array}{l}\text { Toluene/ } \\
\text { ethanol }\end{array}$ & Glass beads & $\begin{array}{l}\text { Lysozyme } \\
\text { (hypotonic } \\
\text { medium) }\end{array}$ \\
\hline Crude extract & $507 \pm 50$ (a) & $500 \pm 50$ & $113 \pm 11$ & $508 \pm 50$ & $348 \pm 35$ & $510 \pm 51$ \\
\hline Supernatant & $167 \pm 17$ & $382 \pm 38$ & $12 \pm 1$ & $100 \pm 10$ & $220 \pm 22$ & $377 \pm 38$ \\
\hline Pellet & $340 \pm 34$ & $117 \pm 12$ & $100 \pm 10$ & $407 \pm 41$ & $126 \pm 13$ & $133 \pm 13$ \\
\hline
\end{tabular}

(a) Results are expressed as $\mu \mathrm{g}$ of proteins (means of 4 experiments).

Note : different values in the crude extract result from the fact that the experiments were performed with different batches of bacterial suspensions. 
TABLE $2-T A B L E A U 2$

Extraction yields of L-serine dehydratase with the different permeabilization and grinding methods used. The results are the means of 4 experiments.

Rendements d'extraction de l'activité par différentes méthodes de perméabilisation ou de broyage. Les résultats sont les moyennes de 4 expériences.

\begin{tabular}{|c|c|c|c|c|c|c|c|c|c|c|c|c|c|c|c|}
\hline & \multicolumn{3}{|c|}{ Triton X-100 } & \multicolumn{3}{|c|}{$\begin{array}{l}\text { Lysosyme } \\
\text { (hypotonic } \\
\text { medium) }\end{array}$} & \multicolumn{3}{|c|}{ Glass beads } & \multicolumn{3}{|c|}{ Sonication } & \multicolumn{3}{|c|}{ Toluene } \\
\hline & $\mathrm{CE}(\mathrm{b})$ & $\mathrm{P}$ & $\mathrm{S}$ & $\mathrm{CE}$ & $\mathrm{P}$ & $\mathrm{S}$ & $\mathrm{CE}$ & $\mathrm{P}$ & $\mathrm{S}$ & $\mathrm{CE}$ & $\mathrm{P}$ & $\mathrm{S}$ & $\mathrm{CE}$ & $\mathrm{P}$ & $\mathrm{S}$ \\
\hline Specific activity(a) & $\begin{array}{l}392 \\
\pm 40\end{array}$ & $\begin{array}{l}583 \\
\pm 6\end{array}$ & 0 & $\begin{array}{c}5 \\
\pm 1\end{array}$ & $\begin{array}{l}8 \\
\pm 1\end{array}$ & 0 & $\begin{array}{c}31 \\
\pm 30\end{array}$ & $\begin{array}{l}16 \\
\pm 2\end{array}$ & 0 & $\begin{array}{c}22 \\
\pm 2\end{array}$ & $\begin{array}{l}21 \\
\pm 2\end{array}$ & 0 & 0 & 0 & 0 \\
\hline $\begin{array}{l}\text { Yield : \% of total } \\
\text { activity }\end{array}$ & 100 & 100 & 0 & 1 & 1 & 1 & 8 & 2 & 0 & 6 & 1 & 0 & 0 & 0 & 0 \\
\hline
\end{tabular}

(a) Specific activity expressed as nmol of pyruvate or $\mathrm{NH}_{4}+$ produced per min and per mg of protein.

(b) $\mathrm{CE}=$ crude extract, $\mathrm{P}=$ pellet, $\mathrm{S}=$ supernatant. 
TABLE $3-T A B L E A U 3$

Subcellular localization of L-serine dehydratase activity after lysozyme treatment in hypertonic medium followed by osmotic shock.

Localisation cellulaire de l'activité L-sérine déshydratase après traitement en milieu hypertonique par le lysozyme, suivi d'un choc osmotique.

\begin{tabular}{l|c|c|c|c|c}
\hline & Crude extract & $\begin{array}{c}\text { Protoplast } \\
\text { supernatant }\end{array}$ & Protoplasts & Membranes & $\begin{array}{c}\text { Intracellular } \\
\text { medium }\end{array}$ \\
\cline { 2 - 5 } Proteins extracted $(\mu \mathrm{g})$ & $510 \pm 50$ & $193 \pm 20$ & $316 \pm 30$ & $83 \pm 10$ & $233 \pm 20$ \\
Specific activity(a) & $390 \pm 40$ & 0 & $202 \pm 20$ & $120 \pm 10$ & 0 \\
Total activity & $198 \pm 20$ & 0 & $64 \pm 5$ & $10 \pm 1$ & 0 \\
Yield of activity \% & 100 & 0 & 32 & 5 & 0 \\
\hline
\end{tabular}

(a) Specific activity is expressed as nmol of pyruvate produced per min and per mg protein. The results are the means of 4 experiments. 


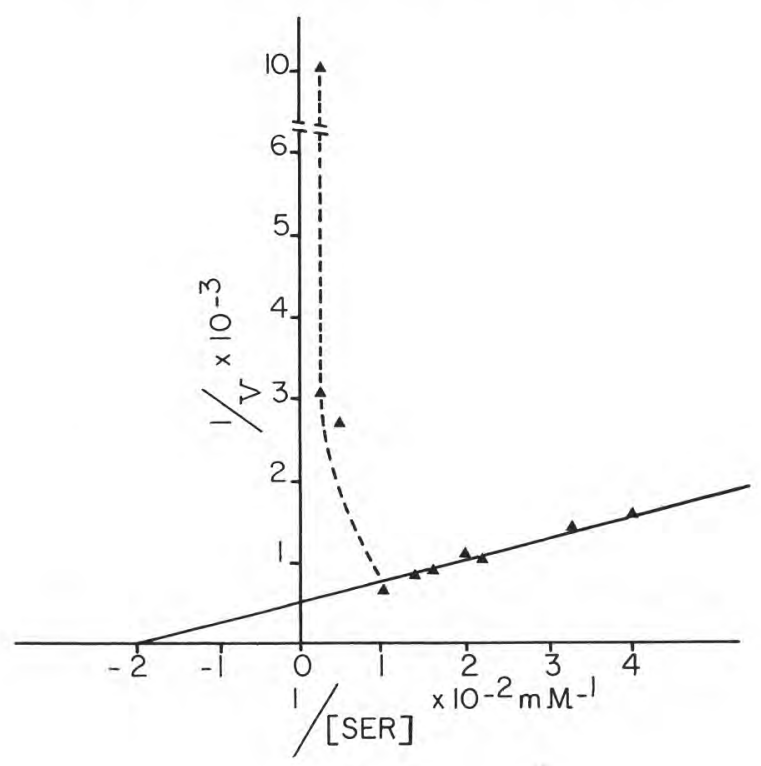

fig. 2

Graphic determination (Lineweaver-Burk) of kinetic constants of L-serine dehydratase activity.

Détermination graphique (selon Lineweaver-Burk) des constantes cinétiques de la L-sérine déshydratase.

the enzyme by the action of DOC or SDS on membrane fractions or cells permeabilized with Triton X-100, there was a total loss of activity. This was true in the absence or presence of protease inhibitors, such as $1 \mathrm{mM}$ para-methylsulfonyl fluoride (PMSF) or parachrloromercuribenzoate (PCMB). It was not possible either to solubilize membranes by increasing the $\mathrm{pH}$, since the enzyme was denatured at alkaline $\mathrm{pH}$ values.

\section{Stability: effect of freezing}

The enzymatic activity of cell suspensions supplemented with $5 \times 10^{-5} \mathrm{M}$ PLP and treated with Triton was not affected by two freeze-thaw cycles, although there was a $40 \%$ loss at the fourth cycle. A single cycle, on the other hand, was sufficient to cause a total loss of activity from protoplasts, membrane extracts, sonicates and glass bead or lysozyme lysates. When $50 \%$ (v/v) glycerol was added to these extracts, residual activity after freezing accounted for one-third of initial activity. Triton-permeabilized cells were thus used for the remainder of the experiments. 


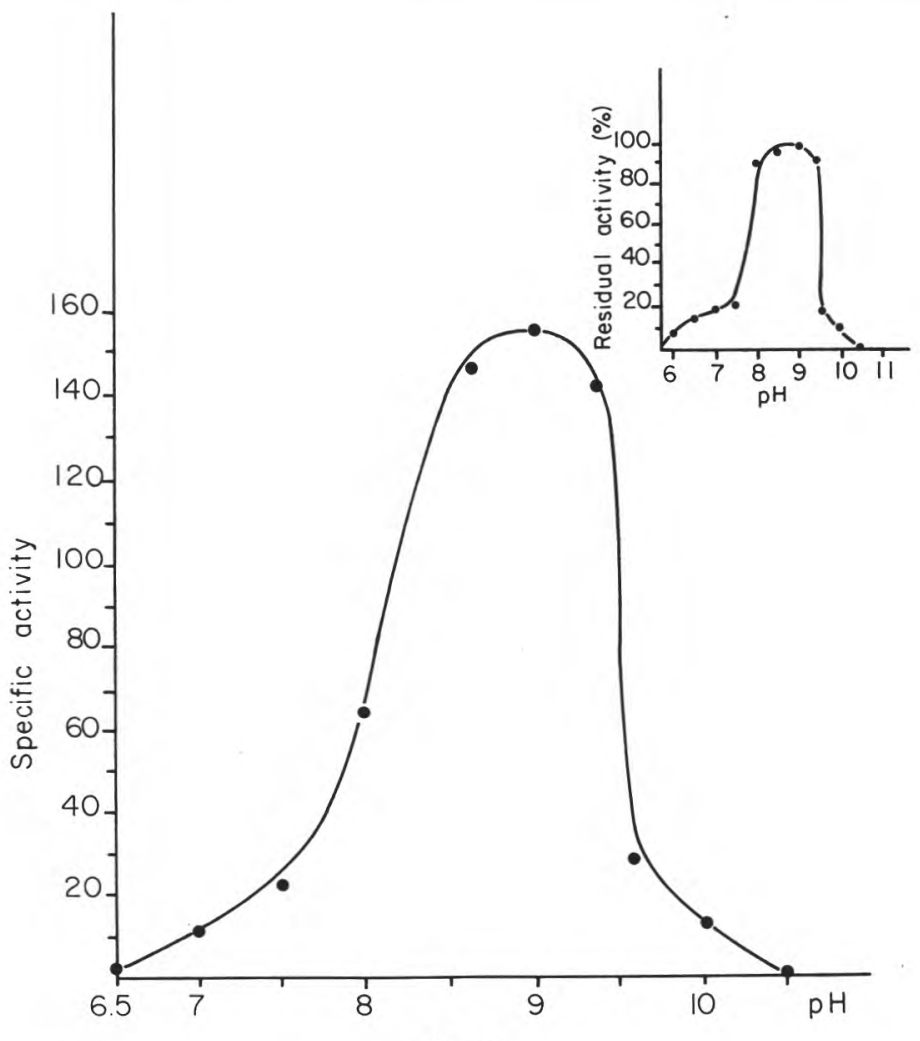

fig. 3

Influence of $\mathrm{pH}$ on the stability and activity of L-serine dehydratase.

Influence du $\mathrm{pH}$ sur la stabilité et l'activité de la L-sérine déshydratase.

\section{Determination of kinetic parameters $\mathbf{K m}_{\text {app }}$ and $\mathbf{V m}_{\text {app }}$}

The quantity of pyruvate produced by the oxidative deamination of L-serine was proportional to cell concentrations used (data not shown). In the presence of $100 \mathrm{mM} \mathrm{L}$-serine and $1.3 \mathrm{mg}$ of dry extract, pyruvate formation was linear for 30 minutes. The value of the apparent $\mathrm{Km}$ was high at $50 \times 10^{-3} \mathrm{M}$ and the $\mathrm{Vm}$ was 200 nmoles of pyruvate formed per min and per mg dry extract. An inhibition by excess substrate was also observed (fig. 2).

\section{E. Effects of temperature and pH}

Pyruvate production was optimal in the $\mathrm{pH}$ range of 8.5 to 9.4 with a maximum at 9.0 (fig. 3). The enzyme was also stable between pH 8.0 and 9.4 (inset, fig. 3). L-serine dehydratase activity was optimal 


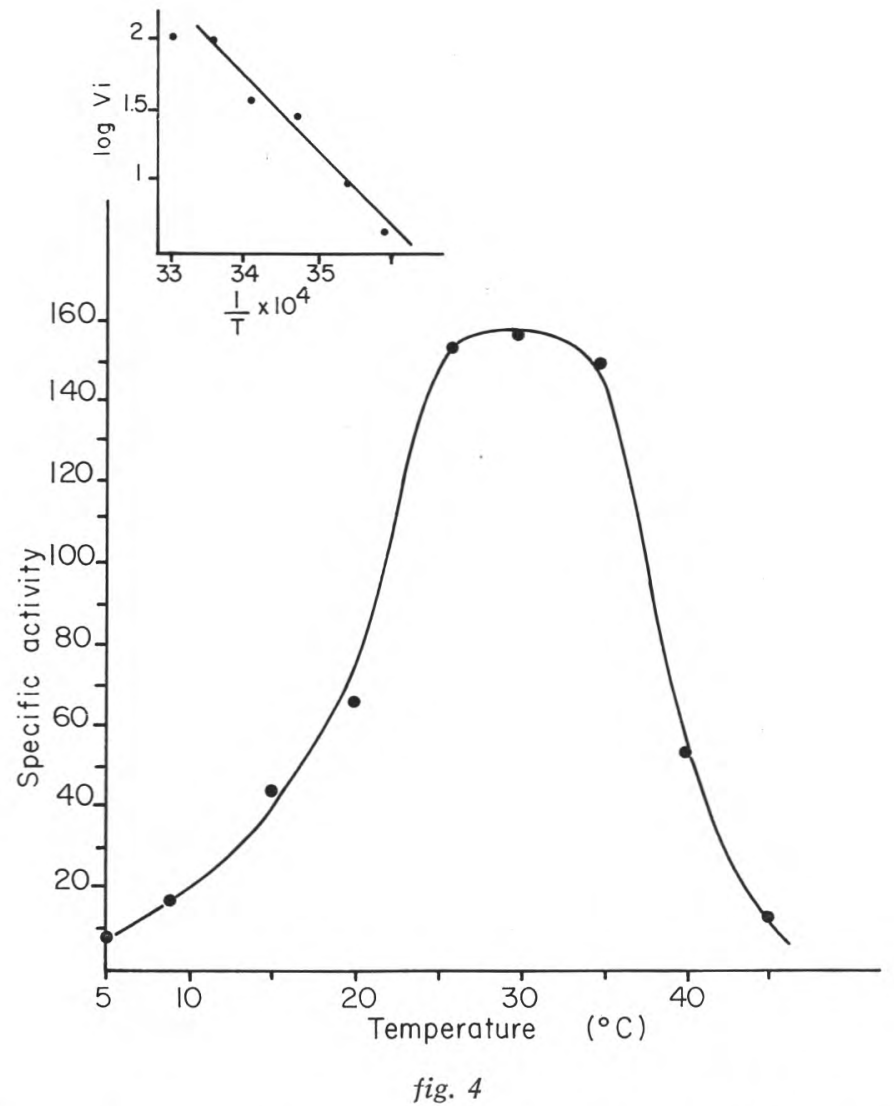

Influence of temperature on the activity of L-serine dehydratase.

Influence de la température sur l'activité de la L-sérine déshydratase.

between 26 and $35^{\circ} \mathrm{C}$ (fig. 4). Thermal inactivation kinetics showed that the enzyme was stable up to $30^{\circ} \mathrm{C}$ with a notable loss of activity at $40^{\circ} \mathrm{C}(75 \%$ loss in $15 \mathrm{~min}$ (fig. 5). The apparent activation energy of the activation reaction, calculated with an Arrhenius plot, is $99.5 \mathrm{kJoules} / \mathrm{mole}$ (inset, fig. 4).

\section{F. Inhibition of activity and specificity of L-serine dehydratase}

Action of substrate analogues and small peptides

The only active substrate among those tested was L-serine: there was no activity with L-threonine. D-serine and 2-aminoethanol were competitive inhibitors (curves not shown). L-cysteine was a non- 


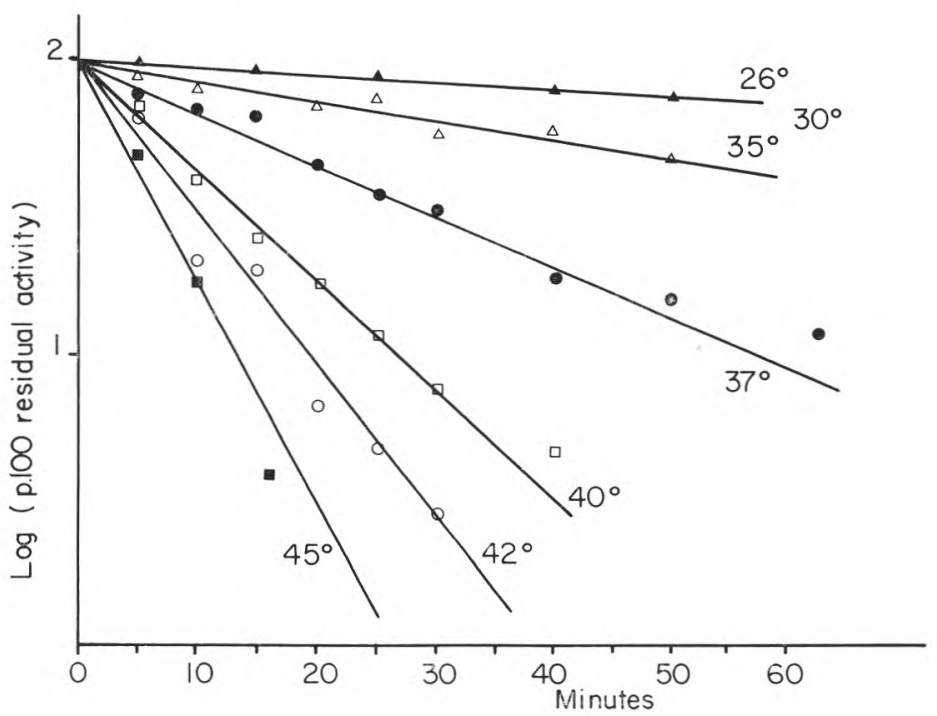

fig. 5

Thermal stability of L-serine dehydratase activity.

Stabilité thermique de la L-sérine déshydratase.

\section{TABLE $4-T A B L E A U 4$}

Effects of substrate analogues on serine dehydratase activity. Effets des analogues de substrats sur l'activité L-sérine déshydratase.

D-serine

2-aminoethanol

L-cysteine

D-cysteine

Serine amide

Serine-0-sulfate

DL-isoserine or

beta-2-thienylserine

Ser-Gly, Ser-Met or

$(\mathrm{Ser})_{3}$

L-threonine or

gamma-aminobutyrate competitive inhibition

competitive inhibition

non-competitive inhibition

non-competitive inhibition

uncompetitive inhibition

inhibition (type not determined)

inhibition (type not determined)

no inhibition 


\section{TABLE 5 - TABLEAU 5}

Influence of various ions on serine dehydratase activity.

Influence de différents ions sur l'activité L-sérine déshydratầse.

\begin{tabular}{|c|c|c|}
\hline & $\begin{array}{l}\text { Final concentration } \\
(\mathrm{mM})\end{array}$ & $\begin{array}{l}\text { Residual activity } \\
\text { (\%) in comparison to } \\
\text { controls without salt }\end{array}$ \\
\hline $\begin{array}{l}\mathrm{NaCl} \text { or } \mathrm{KCl}, \text { or } \\
\mathrm{FeCl}_{2} \text { or } \mathrm{MgCl}_{2}\end{array}$ & $\begin{array}{c}1 \\
10\end{array}$ & $\begin{array}{l}100 \\
100\end{array}$ \\
\hline $\mathrm{LiCl}$ & $\begin{array}{r}1 \\
10\end{array}$ & $\begin{array}{l}65 \\
65\end{array}$ \\
\hline $\mathrm{CaCl}_{2}$ & $\begin{array}{r}1 \\
10\end{array}$ & $\begin{array}{l}90 \\
70\end{array}$ \\
\hline $\mathrm{FeCl}_{3}$ & 1 & 90 \\
\hline $\mathrm{FeSO}_{4}$ & 1 & 80 \\
\hline $\mathrm{ZnCl}_{2}$ & 1 & 90 \\
\hline $\mathrm{HgCl}_{2}$ & 1 & 10 \\
\hline $\mathrm{MnCl}_{2}$ & 1 & 30 \\
\hline \multirow[t]{2}{*}{$\mathrm{NH}_{4} \mathrm{Cl}$} & 50 & 100 \\
\hline & $1+50$ & 150 \\
\hline $\mathrm{KCl}+\mathrm{NH}_{4} \mathrm{Cl}$ & $1+15$ & 115 \\
\hline $\mathrm{KCl}+\mathrm{NH}_{4} \mathrm{Cl}+\mathrm{NaCl}$ & $1+50+15$ & 140 \\
\hline
\end{tabular}

competitive inhibitor and this action could have resulted from chelation by its sulfhydryl group. D-cysteine was thus tested as substrate and inhibitor and no serine dehydratase activity could be demonstrated with this amino acid as substrate. In the presence of both L-serine and D-cysteine, on the other hand, the enzyme was greatly inhibited (Table 4). This would tend to prove that inhibition is independent of cysteine stereochemistry. This amino acid would thus act by chelating an ion required for enzymatic catalysis. These results show that the enzyme is highly specific. The specificity of the enzyme was also shown by the fact that all the serine derivatives tested in the presence of L-serine as substrate caused inhibition, while threonine and gamma-aminobutyrate, structuraly similar, did not inhibit serine dehydratase activity (Table 4). 
TABLE $6-T A B L E A U 6$

Effects of chelators on serine dehydratase activity. Effets des chélateurs sur l'activité L-sérine déshydratase.

\begin{tabular}{c|c|c|c}
\hline \multicolumn{2}{c|}{ EDTA } & \multicolumn{2}{|c}{ o-phenanthroline } \\
\hline $\begin{array}{c}\text { Final } \\
\text { concentration } \\
(\mathrm{M})\end{array}$ & $\begin{array}{c}\text { Residual } \\
\text { activity } \\
(\%)\end{array}$ & $\begin{array}{c}\text { Final } \\
\text { concentration } \\
(\mathrm{M})\end{array}$ & $\begin{array}{c}\text { Residual } \\
\text { activity } \\
(\%)\end{array}$ \\
\hline 0 & 100 & 0 & 100 \\
$10^{-5}$ & 115 & $10^{-7}$ & 80 \\
$10^{-4}$ & 125 & $10^{-6}$ & 80 \\
$10^{-3}$ & 385 & $10^{-5}$ & 60 \\
$10^{-2}$ & 0 & $10^{-4}$ & 45 \\
$10^{-1}$ & 0 & $10^{-3}$ & 25 \\
\hline
\end{tabular}

Effects of ions, chelators and coenzyme (PLP)

These results do not take into account the concentrations of inorganic ions in the preparation, which were not determined. Among the ions tested, only $\mathrm{HgCl}_{2}, \mathrm{MnCl}_{2}$ and to a lesser extent $\mathrm{LiCl}$ decreased activity notably. Ions such as $\mathrm{K}^{+}, \mathrm{NH}^{+}{ }_{4}$ and $\mathrm{Na}^{+}$, combined in pairs or all three together, stimulated activity, although they had no effect individually (Table 5).

Ortho-phenanthroline was a potent inhibitor of L-serine dehydratase (Table 6). In the presence of $1 \mathrm{mM}$ inhibitor, enzyme activity decreased by $75 \%$. Activity was stimulated to a considerable extent in the presence of EDTA, providing its concentration did not exceed $10^{-3} \mathrm{M}$ (Table 6). Inhibition was total at higher concentrations.

The effect of exogenous PLP on activity is striking. At a final concentration of $10^{-5} \mathrm{M}$, activity was increased in comparison to a reaction mixture which did not contain the cofactor (data not shown). Exogenous PLP was unable to reactivate activity lost after freezing.

\section{DISCUSSION}

The detection of L-serine dehydratase activity was optimal in cells permeabilized by Triton X-100. This technique was also used 
by Moses (1972) to render E. coli cells permeable to macromolecules and by Schnaitman (1971) to demonstrate a selective solubility of a large proportion of membrane proteins. Even though the enzyme is bound to the cell envelope, treatment with this mild detergent is the most adequate means for protecting L-serine dehydratase and stabilizing it. A cell support is in fact absolutely necessary, since all attempts at solubilizing the enzyme were ineffective for preserving activity. To our knowledge this is the first report of a membranebound L-serine dehydratase.

The specific activity contained in membranes obtained from lysed protoplasts is 16 times greater than that of the pellet of cells treated with lysozyme in isotonic medium. In this case, it is possible that lysozyme acts differently than in hypertonic medium: it may interact with certain membrane components, as reported by Metcalf and Diebel (1973) for enterococci. The differential specific activity between protoplasts and membranes could be explained by a partial release of the enzyme in the course of osmotic shock (Neu and Heppel, 1965).

Coryneform bacteria are characterized by their particular cycle of development (Komagata et al., 1969; Veldkamp, 1970; Crombach, 1974). The transformation of the bacilloid form to the coccoid form of $B$. linens is characterized by a decrease in L-serine dehydratase activity which is not due to the action of Triton X-100.

L-serine dehydratase is a Michaelis type enzyme with a high apparent $\mathrm{Km}(50 \mathrm{mM})$, although this value is not exceptional. Thus, the enzyme from other species, such as Pseudomonas cepacia (Wong and Lessie, 1979) and E. coli K12 (Newman and Kapoor, 1980) has a $\mathrm{Km}$ on the same order of magnitude or even higher, respectively $2 \times 10^{-2} \mathrm{M}$ and $42 \times 10^{-2} \mathrm{M}$. The same is true of eukaryotes (rat liver cells): $5 \times 10^{-2} \mathrm{M}$ to $8 \times 10^{-2} \mathrm{M}$ (Suda and Nakagawa, 1971; Selim and Greenberg, 1959). Newman and Kapoor (1980) formulated a hypothesis according to which this determination of the Km with E. coli K12 was determined with an inactive or partially inactivated form of the enzyme. In the case of $B$. linens 9175 , treatment with Triton X-100 is not responsible for this type of inactivation. The L-serine dehydratase activity (determined by assaying $\mathrm{NH}^{+}{ }_{4}$ ions) of intact non-permeabilized cells exhibits the same $\mathrm{Km}$ values (Hamouy, 1983).

In the system of permeabilized cells which we used in this study, the enzyme is stable to freezing. This had been reported by Miozzari et al. (1978) for other enzymes such as threonine dehydratase. Moreover, L-serine dehydratase activity in B. linens 9175 is independent of the rate at which the cell suspension is frozen. Samples frozen in liquid nitrogen or in a home freezer $\left(-20^{\circ} \mathrm{C}\right)$ exhibited identical activities. This system of permeabilized cells presents a 
number of advantages, of which the two most important are the high stability of enzymes and the possibility of measuring activity in situ without inactivation or the dissociation of enzyme complexes (Hobot et al., 1982; Weitzman, 1973).

The $\mathrm{pH}$ optimum is high. The $\mathrm{pH}$ optimum of serine dehydratases is generally slightly alkaline with a mean value close to 8 . Thus, it is 8 to 9 for Corynebacterium sp. (Morikawa et al., 1974), 8 to 9 for E. coli (Alföldi et al., 1968), 8 to 8.4 for Cl. acidi-urici (Sagers and Carter, 1971), 6 to 9 for Klebsiella aerogenes (Vining and Magasanik, 1981 ) and 6.5 to 9.5 for Pseudomonas cepacia (Wong and Lessie, 1979).

L-serine dehydratase is specific for L-serine. The non-competitive inhibition by L-cysteine is interesting since this amino acid is generally cited as being a competitive inhibitor of the enzyme (Alföldi et al., 1968; Suda and Nakagawa, 1971; Morikawa et al., 1974; Gannon et al., 1977). In the case of B. linens, it would appear that cysteine acts as a chelator. This is an isolated event, while reducing agents such as hydrosulfite, glutathione, 2-mercaptoethanol, dithiothreitol and cysteine are required for activity in $\mathrm{Cl}$. acidi-urici (Benziman et al., 1960; Suda and Nakagawa, 1971). D-serine is a competitive inhibitor in $B$. linens 9175 , while it has no effect in $\mathrm{Cl}$. acidi-urici (Benziman et al., 1960) and S. cerevisiae (Ramos and Wiame, 1982). L-threonine inhibits in A. globiformis (Gannon et al., 1977) and E. coli (Newman and Kapoor, 1980), but has no inhibitory effect in B. linens 9175.

Results obtained with o-phenanthroline, L-cysteine and $\mathrm{HgCl}_{2}$ would tend to show that a metal ion, probably $\mathrm{Fe}^{2+}$ participates in the enzymatic catalysis; this has been shown in other cases (Benziman et al., 1960; Carter and Sagers, 1972; Newman and Kapoor, 1980). In addition, $\mathrm{Fe}^{2+}$ is absolutely necessary for L-serine dehydratase activity in Cl. acidi-urici (Carter and Sagers, 1972). The stimulation of activity by combinations of $\mathrm{KCl}, \mathrm{NaCl}$ and $\mathrm{NH}_{4} \mathrm{Cl}$, has not been reported for other bacterial L-serine dehydratases. Stimulation of activity by EDTA $\left(10^{-3} \mathrm{M}\right)$ is not clearly explained. In E. coli $\mathrm{K} 12$, on the other hand, this chelator has no stimulatory or inhibitory effect (Newman and Kapoor, 1980). The effect of exogenous PLP on activity is notable, although it has no effect in Cl. acidi-urici (Sagers and Carter, 1981) or in A. globiformis (Gannon et al., 1977). PLP has no stabilizing role in $B$. linens 9175 : it cannot reactivate the enzyme, as it can in S. cerevisiae (Ramos and Wiame, 1982) and in rat hepatocytes (Selim and Greenberg, 1959).

\section{ACKNOWLEDGEMENTS}

Part of this work was supported by Contract No. 81 C 1298 TAA 046, from the Industry and Research Ministry. 


\section{REFERENCES BIBLIOGRAPHIQUES}

Accolas J.P., Melcion D., Vassal L, 1978. Etude de la flore superficielle des fromages de Gruyère et de Beaufort. In $X X^{e}$ Cong. Int. Lait., Paris Edited by F.I.L., Bruxelles, p. 773-774.

Ades G.L., CONE J.F., 1969. Proteolytic activity of Brevibacterium linens during ripening of trappist-type cheese. J. Dairy Sci., 52, 957-961.

Alföldi L., RASKo I., Kerekes E., 1968. L-serine deaminase of Escherichia coli. J. Bacteriol., 96, 1512-1518.

Benziman M., Sagers R.D., Gunsalus I.C., 1960. L-serine specific dehydrase from Clostridium acidiurici. J. Bacteriol., 79, 474-479.

Boyaval P., Desmazeaud M.J., 1983. Le point des connaissances sur Brevibacterium linens. Lait, 63, 187-216.

Brandl E., 1978. Die Bakterien den Kaseoberflache. In $X X^{e}$ Cong. Int. Lait., Paris. Edited by F.I.L., Bruxelles, p. 1-10.

BRIDGELAND E.S., JoNES K.M., 1965. L-serine dehydratase of Arthrobacter globiformis. Biochem. J., 94, 29 p.

CARTER J.E., Sagers R.D., 1972. Ferrous ion-dependent L-serine dehydratase from Clostridium acidiurici. J. Bacteriol., 109, 757-763.

CROMBACH W.H.J., 1974. Morphology and physiology of coryneform bacteria. Antonie Van Leeuwenhoek, 40, 361-376.

DUMONT J.P., AdDA J., 1978. Flavour formation in dairy products. In Progress in Flavour research. Edited by D.G. Lang and H.E. Nurstein, London. Applied Sciences Publishers, p. 245-262.

EL ERIAN A.F.M., 1972. Bacteriological studies on Limburger Cheese. Neth Milk Dairy J., 26, 113-116.

FoIssy H., 1974. A method for demonstrating bacterial proteolytic iso-activities after electrophoresis in acrylamide gels. J. Appl. Bacteriol., 37, 133-135.

Forssy H., 1978 a. Aminopeptidase from Brevibacterium linens : production and purification. Milchwissenschaft, 33, 221-223.

ForssY H., $1978 \mathrm{~b}$. Some properties of aminopeptidase from Brevibacterium linens. FEMS Microbiol. Lett., 3, 207-210.

Forssy H., 1978 c. Aminopeptidase from B. linens. Activation and inhibition. Zeit. Lebensmitt. und-Fors., 166, 164-166.

Friedemann T.E., Haugen G.E., 1943. The determination of keto-acids in blood and urine. J. Biol. Chem., 147, 415-442.

Friedman M.E., Nelson W.O., Woon W.A., 1953. Proteolytic enzymes from Bacterium linens. J. Dairy Sci., 36, 1124-1134.

Gannon F., Bridgeland E.S., Jones K.M., 1977. L-serine dehydratase from Arthrobacter globiformis. Biochem. J, 161, 345-355.

GRIFFITHS S.K., DE Moss R.D., 1970. Physiological comparison of L-serine dehydratase and tryptophanase from Bacillus alvei. J. Bacteriol., 101, 813-820.

Hamouy D., 1983. Etude du catabolisme de la sérine chez Brevibacterium linens. Thèse, Université Paris XI.

Hemme D., Bouillanne C., Metro F., Desmazeaud M.J., 1982. Microbial catabolism of amino acids during cheese ripening. Sci. Aliments, 2, 113-123.

Herbert D., Phipps P.J., Strange R.E., 1971. Chemical analysis of microbial cells. Determination of protein with Folin-Ciocalteu reagent. In Methods in Microbiology $5 B$. Edited by J.R. Norris and D.W. Ribbons, New York, Academic Press, p. 249-252.

Новот J.A., Felix H.R., Kellenberger E., 1982. Ultrastructure of permeabilised cells of Escherichia coli and Cephalosporium acremonium. FEMS Microbiol. Lett., 3, 57-61.

Hosono A., 1968. Production of volatile fatty acids by Brevibacterium linens. I. Formation of volatile fatty acids from individual amino acids. Jap. J. Zootech. Sci., 39, 156-161. 
IsENBerg S., NEwman E.B., 1974. Studies on L-serine deaminase in Escherichia coli K12. J. Bacteriol., 118, 53-58.

Komagata K., Yamada K., Ogawa H., 1969. Taxonomic studies on coryneform bacteria. I. Division of bacterial cells. J. Gen. Appl. Microbiol., 15, 243-259.

Melcalf R.H., Deibel R.H., 1973. Effect of lysozyme on enterococcal viability in low ionic environments. J. Bacteriol., 113, 278-286.

MTOZZARI G.F., NIEDERBERGER P., HüTTER R., 1978. Permeabilization of microorganisms by Triton X-100. Anal. Biochem., 90, 220-233.

Morikawa Y., Nakamura N., Kimura K., 1974. Purification and some properties of L-serine dehydratase of Corynebacterium sp. Agr. Biol. Chem., 38, 531-537.

MorRIs J.G., 1963. The assimilation of 2-C compounds other than acetate. J. Gen. Microbiol., 32, 167-170.

Moses R.E., 1972. Replicative deoxyribonucleic acid synthesis in a system diffusible for macromolecules. J. Biol. Chem., 247, 6031-6038.

NeU H.C., HePPEL L.A., 1965. The release of enzymes from Escherichia coli by osmotic shock and during the formation of spheroplasts. J. Biol. Chem., 240, 3685-3692.

NeWman E.B., KaPOOR V., 1980. In vitro studies on L-serine deaminase activity of Escherichia coli K12. Can. J. Biochem., 58, 1292-1297.

Ramos F., Wiame J.M., 1982. Occurrence of a catabolic L-serine (L-threonine) deaminase in Saccharomyces cerevisiae. Eur. J. Biochem., 123, 571-576.

Raskó I., Kerekes E., Alföldi L., 1969. Properties of L-serine deaminase from Salmonella typhimurium and Bacillus cereus. Acta Microbiol. Hung., 16, 237-244.

Regnier Ph., Thang, 1979. Masked proteolytic activity localized in the outer membrane of Escherichia coli. FEBS Lett., 102, 291-296.

RICHARD J., ZADI H., 1983. Inventaire de la flore bactérienne dominante des Camemberts fabriqués avec du lait cru. Lait, 63, 25-42.

Sagers R.D., Carter J.E., 1971. L-serine dehydratase (Clostridium acidiurici). In Methods in Enzymology, XVII (B). Edited by H. Tabor and C.W. Tabor, New York, Academic Press, 351-356.

Schnartman C.A., 1971. Solubilization of the cytoplasmic membrane of Escherichia coli by Triton X-100. J. Bacteriol., 108, 545-552.

Selim A.S.M.., Greenberg D.M., 1959. An enzyme that synthesizes cystathionine and deaminates L-serine. J. Biol. Chem., 234, 1474-1480.

Serrano R., Gancedo J.M., Gancedo C., 1973. Assay of yeast enzymes in situ. A potential tool in regulation studies. Eur. J. Biochem., 34, 479-482.

SøRHAUG T., ØRDAL Z.J., 1974. Cell-bound lipase and esterase of Brevibacterium linens. Appl. Microbiol., 27, 607-668.

SudA M., NAKAgawa H., 1971. L-serine dehydratase (Rat liver). In Methods of enzymology. XVII B. Edited by $\mathrm{H}$. Tabor and C.W. Tabor, New York, Academic Press, p. 346-351.

Thomasow J., 1950. Uber Enzyme des Bacterium linens. Kieler Milchw. Forsch., 2, 35-62.

VEISSEYRE R., 1975. In Technologie du lait. $3^{e}$ édition. Edited by Paris : La Maison Rustique, p. 452-548.

Veldkamp H., 1970. Saprophytic coryneform bacteria. Ann. Rev. Microbiol., 24, 209-240.

Vining L.C., Magasanik B., 1981. Serine utilization by Klebsiella aerogenes. $J$. Bacteriol., 146, 647-655.

WANG C.S., SMITH R.L., 1975. Lowry determination of protein in the presence of Triton X-100. Anal. Biochem., 63, 414-417.

WeITZMAN P.D.J., 1973. Behaviour of enzymes at high concentration. Use of permeabilised cells in the study of enzyme activity and its regulation. FEBS Lett., 32, 247-250.

WONG H.C., Lessie T.G., 1979. Hydroxyaminoacid metabolism in Pseudomonas cepacia : role of L-serine deaminase in dissimilation of serine, glycine and threonine. J. Bacteriol., 140, 240-245. 